Section 4:

Planning, Preparing, and Reality 


\section{Maritime Operations and Missions: The Falklands Case}

\section{Chris Parry}

\section{Introduction}

The Falklands War of 1982 was an anomaly within the context of the Cold War. Despite periodic shadow-boxing (most recently in 1979), no one anticipated that Britain and Argentina, the ally and partner respectively of the United States (US) in common opposition to the Soviet bloc and whose political, economic and military ties were stable, if not exactly close, would come to blows. Nevertheless, in April 1982, an Argentinian military junta, under pressure because of its political, economic and human rights record, authorised an opportunist seizure of the Falklands, only to find a British democratic regime, itself under pressure because of its falling popularity and weak economic stewardship, equally prepared to exploit an opportunity, by first threatening and then using force, to regain the islands.

The defence posture of each country certainly did not reveal overt plans for a high impact conflict with the other. Argentina's defence policy centred on capabilities required to provide deterrence and defence in relation to its neighbours, notably with Chile, against which it also harboured territorial ambitions; to assure the US of its reliability as a partner in a region susceptible to Marxist leanings; and to maintain coercive control over its population. Meanwhile, the United Kingdom's strategic posture and defence policy was predicated on membership of the NATO alliance. As a result, British threat analysis, procurement and fighting doctrine was geared towards the challenge of the Soviet Union and the Warsaw Treaty Organisation (WTO) in Central Europe and a maritime focus on the North Atlantic, the Norwegian Sea, the Channel and the Baltic. This formed part of a NATO maritime strategy that envisaged containment of the Soviet Northern and Baltic Fleets, forward defence in depth and the holding of the Iceland-Faroes-UK line in order to ensure the safe arrival of reinforcement shipping from North America. The principal threats would be missile and torpedo firing submarines and long-range aircraft armed with high-trajectory anti-ship missiles. 
British defence policy and the 'nott review'

Consequently, British defence strategy relied on the assurance that allied, notably US, capabilities would be available, both to supplement UK and other allied capabilities and to cover significant capability shortcomings. There was also the implicit but vague understanding that British forces that were trained and equipped to deter and defeat the WTO within the structure of NATO would be sufficient to deal with any out-of-area threat to British dependencies (as they were then known). ${ }^{1}$ No detailed attention had been paid at either the government or military level to the action and capabilities that might be necessary in the event of hostile powers threatening or seizing these dependencies, most of which were at extended distances from the UK. ${ }^{2}$

The 'Nott Review' of $1981^{3}$ reinforced this posture, while reducing expenditure in response to an economic recession in the early 1980s, even though defence spending constituted 5.2 per cent of GDP. ${ }^{4}$ Its focus unflinchingly remained on support of NATO on the Central Front in Europe and the transatlantic reinforcement routes, with scarcely a mention of Britain's out-of-area commitments. ${ }^{5}$ It assumed that UK forces would not deploy on combat operations outside the NATO area and then only with the participation of allies and within range of land-based air support.

1 'We exploit the flexibility of our forces beyond the NATO area so far as our resources permit, to meet ... specific British responsibilities', CMND 8288, 'The UK Defence Programme: The Way Forward' (HMSO, 1981), 5. After the Falklands War, it was reiterated that 'the policy of successive Governments has been that operations outside the NATO area should be undertaken by forces whose primary role is in support of the Alliance', CMND 8758, The Falklands Campaign: The Lessons (HMSO, 1982), 32.

2 In practice, the Royal Navy retained the capability of what was termed out-of-area deployments and intervention, notably in the Caribbean and in the Gulf region (based on the ARMILLA patrol) and periodically engaged in group deployments to the Asia-Pacific region. It also routinely operated off the US East Coast for training and in support of major NATO exercises in the North Atlantic.

3 More precisely, 'The UK Defence Programme: The Way Forward' Command 8288'. This major review of the United Kingdom's defence policy was conducted by the Conservative government of the Prime Minister Margaret Thatcher. Its main sponsor, and proponent, was the then Secretary of State for Defence, John Nott.

4 Command $8288,3$.

5 'We have now four main roles: an independent element of strategic and theatre nuclear forces committed to the Alliance; the direct defence of the United Kingdom homeland; a major land and air contribution on the European mainland; and a major maritime effort in the Eastern Atlantic and Channel' (Command 8288, 5). 
There would be no need for a UK amphibious assault. ${ }^{6}$ It breezily and fleetingly mentioned that 'our forces will also continue as necessary to sustain specific British responsibilities overseas, for example in Gibraltar, Cyprus, Belize and the Falkland Islands'. ${ }^{7}$ It even stated an unintentionally prophetic but vague intention 'to resume from 1982 onwards the practice of sending a substantial naval task group on long detachment for visits and exercises in the South Atlantic, Caribbean, Indian Ocean or further east'. ${ }^{8}$ It claimed, without irony, to be a 'realistic, unsentimental and up-to-date judgement of what will be most relevant and effective in future years'.

The Nott Review (and its predecessors) reflected attempts by governments to reconcile ends (what the public and politicians wanted), means (what they could afford) and ways (the ability of a country to deliver in human, militarily practical and technological terms). The trick was not to spend too much on defence, in case the public complained, and not too little, lest defence appeared no longer credible in deterring opponents and rivals and in reassuring allies. Unfortunately, national policies tend to reflect consensual rather than objective assessments about the future, the imperatives of steady-state administration and a 'strategic narcissism [that] leads to policies and strategies based on what the purveyor prefers, rather than on what the situation demands'. ${ }^{10}$ These features are often compounded by an ignorance or misuse of history, a neglect of hard-won lessons and the use of simplistic analogies that mask flaws in policy or strategy. Worse still, the resulting strategy is rarely a template for the pressing demands and practicalities of warfare should policy and deterrence fail and the armed forces are required to fight, which can lead to situations where the declared ends of policies and national strategies rarely balance the ways and means by which they can be put into practice. Put simply, if you insert something into national strategy, you should mean it.

6 The work associated with the review discounted Britain's need for aircraft carriers or amphibious forces, and its provisions and projections have generally been considered to have been one of the contributing factors that encouraged Argentina to seize the Falkland Islands.

7 Command 8288,11 . It signally failed to differentiate between the threat levels associated with these territories.

8 Command 8288, 11.

9 Command 8288, 14.

10 H. R. McMaster, Battlegrounds: The Fight to Defend the Free World (William Collins, 2020), 56. 


\section{The Falklands case}

These aspects and the 'wide gap between the assumptions on which some policies and strategies [were] based and the reality of situations on the ground'11 characterised Britain's experience in the Falklands War. Seen through the lens of the South rather than the North Atlantic, the Royal Navy was deficient in several categories of high-end warfighting capacity, the availability of which had been taken for granted in the event of a war or conflict within an allied structure. These included Airborne Early Warning, land-based combat aircraft, a large fleet of logistics support and the defence in depth and combat power associated with US Carrier Battle Groups and their associated air wings. In addition, there was reasonable uncertainty as to whether the platforms, systems and trained manpower that had been prioritised against the WTO would be as effective against an opponent deploying weapons and systems supplied by the West in the distant waters of the South Atlantic. It is significant that most senior civilian and military experts in both the US and the UK assessed the enterprise to be unfeasible.

Nevertheless, the political imperative to retake the Falklands allowed many of the operational and tactical shortcomings that were implicit in strategic-level planning to be glossed over amid the prevailing enthusiasm and 'can-do' attitude. The risks inherent in deploying out-of-area, with every element of combat power having to be transported 8000 miles into a hostile theatre, were only loosely calibrated in comparisons between existing policy and strategy assumptions and the context of the South Atlantic. There was confidence that continuous individual and collective training, operational efficiency and participation in large-scale NATO exercises, coupled with a high level of technological sophistication, would allow the Royal Navy to prevail. Unfortunately, as in this case, however much navies anticipate the technologies and tactics required to mitigate generic risks, they generally fail to implement rigorous programmes of material preparation and training to meet specific contexts and threats, especially those they do not expect to face or do not fully assess. The result for the British, and to an extent the Argentinians, was that their armed forces ended up 'learning by doing' (often the hard way).

In the event, the British comprehensively won the war. From a balanced fleet of carriers, amphibious ships, submarines, destroyers, frigates and

11 H. R. McMaster, Battlegrounds, Introduction. 
afloat support ships, ${ }^{12}$ nuclear submarines, the contribution of naval and other embarked aviation (especially the SEA HARRIER and AIM-9L SIDEWINDER air-to-air missile combination) and professional, experienced land units were decisive in narrowing the marginal force ratios that the British faced in theatre. ${ }^{13}$ Their baseline level and breadth of capability and experience allowed for innovation and improvisation in the face of fluid operational circumstances, not least in response to the unexpected challenge of facing Western-derived weapons systems and the need for novel tactics and techniques on those occasions when the balance of relative fighting power did not favour them. ${ }^{14}$

In particular, the deployment of the Task Force in short order and the establishment of the logistical lines of communication necessary to sustain the operation over 8000 miles were possible because British warships were manned, stored and equipped to NATO warfighting levels, with a high level of operational and technical readiness and near full ammunition states. The warships and aircraft were able to fight on a 'come as you are' basis, although with very little opportunity for the British to fit them with enhancements or specialist role equipment in order to adapt them specifically to the South Atlantic case. It might be remarked that this ability to transition quickly from peace to war in 1982 contrasts with the situation today in most free world navies that maintain peacetime levels of readiness and capability, on the basis that there will always be time and resources to prepare for operations and war. In an emerging future of strategic competition and potentially contested sea spaces, this approach is likely to need reassessment and adjustment.

12 The effort required the commitment of 26 warships and submarines (later rising to 44) supported by 24 ships of the Royal Fleet Auxiliary and Royal Maritime Auxiliary Service, as well as 54 requisitioned civilian ships taken up from trade (STUFT).

13 The operation also benefited from long-range air reconnaissance, strike and refuelling sorties from the small British territory of Ascension Island, 3800 miles from the Falklands, as well as an extensive air transportation bridge between the United Kingdom and Ascension.

14 In this aspect, there is a clear echo of the US naval experience at Guadalcanal from July 1942 onwards (Richard B. Frank, Guadalcanal (New York, Random House, 1990), 123. 
Some lessons for strategic planners

Detailed lessons, including improvements and enhancements to materiel, systems and weapons required after the Falklands War, were contained in Command 8758, The Falklands Campaign: The Lessons (HMSO 1982) and need no further comment here. Several other features are of general relevance and interest to strategic and operational planners today.

The first of these is that navies need to prepare and equip themselves for war in general, not exclusively for any particular war or scenario. It pays to remember that you rarely get-or are prepared for-the war that you have to fight. In 1982, the British human and systems capabilities were benchmarked against the Soviet Union, which would now be termed a peer-plus opponent. As such, they should in theory have overmatched an opponent with less operational experience and technical sophistication. However, it needs to be recalled that only a proportion of the armed forces of each country were engaged in the war and neither home country was under threat. Owing to the geographic proximity of the Falklands to Argentina and the limited size of the British deployment, Britain was effectively acting as if it were one of Argentina's local opponents and was not able to fight the war as it would have liked.

As a result, the risks for a predominantly oceanic navy were substantially increased and underestimated, especially in it having to impose and maintain a territorially anchored exclusion zone and to operate close inshore. It initially faced a significant challenge from the Argentinian navy (until, except for the submarine ARA San Luis, it withdrew after the sinking of ARA General Belgrano) and a constant threat from a capable air force and naval air arm which were able to generate, in relative terms, high sortie rates against topographically constrained warships and a small number of Sea Harriers. This blind spot was compounded, or perhaps caused, by unrealistic expectations about weapons and sensor performance, especially in the absence of Airborne Early Warning. Justifiable concerns about the low numbers of Sea Harriers and the performance of air surveillance and target acquisition radars close to land and against missiles and aircraft at extremely low levels were discounted, as was the fact that only the radars in the two Type 22 frigates possessed automatic moving target indicator features. Both Seadart (with which the Argentinians were intimately familiar) ${ }^{15}$ and Seaslug medium-range anti-air missiles were only suitable for engagements well out to sea and against targets that obliged by flying at suit-

15 By virtue of operating two British derived Type 42 destroyers. 
able engagement altitudes. Meanwhile, there was very little confidence in the ability of the widely fitted Seacat anti-air missile to hit agile, manoeuvring targets. ${ }^{16}$

Another major British deficiency was the ducted sonars in surface ships, although this did not result in catastrophic losses. ${ }^{17}$ The Royal Navy operated up to and after the war with obsolete sonars which seldom delivered acoustic detections outside the range at which any self-respecting submariner would fire a torpedo. For decades in the Cold War, and in the Falklands War, Royal Navy surface ships persisted in transmitting on sonars, which is associated with similarly archaic tactics, whose primary unwitting purpose (owing to extended counter-detection ranges) was to attract the very submarines that they were supposed to detect. It was well into the $21^{\text {st }}$ century before suitable surface ship active sonars (such as Low Frequency Active Sonars and bi-static arrays) became available in order to detect submarines at operationally useful ranges, along with tactics that further privileged the role of helicopters, aircraft and other submarines.

\section{Sustainability}

Another risk for the British was that the conflict quickly became a war of attrition and a critical issue centred on which side was able to stay in the fight long enough to achieve its (limited) objectives. Consequently, it was crucial that each opponent should not be able to determine the point at which one side's ability to continue to fight could be seen to be exhausted by its inability to access sources of materiel, stores and munitions. Britain moved quickly to ensure that additional Exocet missiles did not reach Argentina and secured a series of UN resolutions that not only isolated the Falklands geographically, but also choked off sources of material and armament supply to Argentina. As a result, the shortage of technical spares available to the Argentinian Type 42 destroyers and Type 209 submarines was known to the British, as was the number of AM-39 Exocets. These features and other intelligence about Argentina's restricted sustainability and access to supply chains fundamentally defined the geometry of the con-

16 Seacat's capabilities were well known to the Argentinians through their own Tigercat systems.

17 The same deficiency was apparent in the Argentinian Navy, as was evident with the loss of the General Belgrano. 
flict. ${ }^{18}$ Conversely, Britain was able to secure essential supply from the US, most notably the AIM-9L Sidewinder air-to-air missiles, mortar rounds and 12.5 million tons of aviation fuel. ${ }^{19}$ For their part, the Argentinians never made a concerted effort to interdict the British lines of logistics communications. ${ }^{20}$ Despite the fact that the Argentinians had plenty of combat materiel on land (but little food for the troops), the progressively high rate of attrition among the Argentinian Air Force and naval air arm aircraft and aircrews (and in having only two AAR C-130s) ${ }^{21}$ seriously limited the extent to which they could sustain sortie rates to prevent the islands being recaptured. At no stage did the Argentinians make a concerted effort, other than trying to eliminate one or both of Britain's aircraft carriers, to empty the Task Force's locker of Sea Harriers by engaging in systematic air-to-air combat. Nor were they able to conduct a sufficiently robust defence of the islands long enough for the Antarctic winter season and logistics shortages to frustrate British attempts to force a surrender. ${ }^{22}$

This factor is highly relevant today as countries of the free world face the prospect of strategic competition with states, like China and Russia, that have the military strength and indigenous industrial capacity to sustain a high operational tempo over an extended period. Conversely, the military and naval capacities and supply chains of most countries in the free world, apart from the United States, are explicitly finite, with long lead-in times for the production of increasingly scarce platforms and systems across all environments, not least in the maritime dimension.

\section{Individual and collective training}

A key principle in relation to military effectiveness and improvisation is the value of training and exercises replicating how a country intends to op-

18 Even though Argentina was able to procure additional fighter-bombers from Peru and MANPADS anti-air systems from Libya.

19 A more complete list includes 200 Sidewinder anti-aircraft missiles, eight Stinger anti-aircraft systems, Harpoon anti-ship missiles (for Nimrods), mortar shells, satellite intelligence, communications facilities and the use of Wideawake Airfield on Ascension Island.

20 Late in the campaign, C-130 aircraft were equipped to carry bombs and attacked two ships, the tanker British Wye and the Hercules.

21 In addition, the Mirage Vs were unable to conduct AAR.

22 The British had planned for this possibility in their earlier seizure of South Georgia, whose Cumberland Bay would have provided a makeshift base for the Task Force and its operations had the war continued into the winter months. 
erate or fight during a conflict. ${ }^{23}$ In the 1980s, Royal Navy warships and other units were trained individually and collectively to a high standard of operational efficiency, provoking the comment in several memoirs that combat in the Falklands resembled a live version of the training with which all were familiar. ${ }^{24}$ Likewise, the idea that the training ground should be the battleground worked in Britain's favour. The Royal Navy and its Royal Marines had extensive experience of operating in the arduous conditions of the North Atlantic and the more severe conditions of the Norwegian Sea and the Arctic. They therefore adapted readily to the extreme environmental conditions of the South Atlantic. This aspect argues more broadly for naval forces to deploy and exercise regularly in areas of strategic interest so that they acquire sufficiently comprehensive familiarity with a context in which they might have to fight. Similarly, the detailed study of previous naval 'battlegrounds' is an underused resource, with benefits for the moral and conceptual components of fighting power, not least in extracting examples of best operational practice, command understanding and contextual awareness.

\section{Action damage}

A related issue is that of Action Damage. Before the Falklands conflict, persistently overly optimistic assumptions prevailed with regard to platform survivability and equipment resilience, not only in the inadequate provision of appropriate firefighting and damage control measures (notably smoke limitation and breathing apparatus), but also about the scale of direct and collateral damage that could be inflicted by anti-ship missiles, bombs or torpedoes. It is significant that three Type 42 destroyers did not last long in the conflict, having been struck by a single non-detonating Exocet missile (SHEFFIELD), three $500 \mathrm{lb}$ bombs, only one or two of

23 Very few navies have come close to the Imperial Japanese Navy's high-risk approach of tactical realism and live fire exercises before World War II, which resulted in frequent ship and aircraft casualties, but stimulated a highly aggressive fighting spirit and a pronounced initial advantage in night operations.

24 Of course, there are limits to the amount of operational and tactical realism that is possible in exercises and training, as no objective short of conflict justifies the category of risks that might be necessary in war. Fortunately, this is an area where simulation and gaming can increasingly assist visualisation and permit repeated practice, especially in the emerging world of augmented and mixed-reality technologies. 
which exploded (COVENTRY), and a single $500 \mathrm{lb}$ bomb, which did not explode (GLASGOW). Conversely, older ships, such as the Type 12 and LEANDER class frigates and the County class destroyers, were able to absorb damage. Planning and training had rarely taken into account, and rarely considers today, the extent to which platforms and people have to be tough, be able to absorb action damage and sustain the physical rigours and mental terrors of combat. A modern warship might recover sufficiently to be able to float and even move, but it is unlikely to be able to continue fighting, and the risk, survivability and cumulative force ratio implications of a warship being struck by a cruise missile, bomb or a heavyweight torpedo are rarely considered at the strategic level of planning.

\section{Weapons planning}

Anticipated weapons use is always underestimated by the proponents of policy or strategic plans. Unsurprisingly, the high rates of consumption of all types of ammunition, equipment and specialist stores by the British were recognised after the war, to the extent that there was a comprehensive review of 'the size and composition of the stockpile intended to support operations outside the NATO area and its relationship to NATO war stocks'. ${ }^{25}$ Engagement criteria in combat can never be entirely precise owing to the margin of error inherent in risk assessment and in the detection and classification of potential threats. In the Falklands, this was especially the case in anti-submarine warfare, which, on the British side, had to deal with complicated acoustic contexts and a diverse range of plausible detections, including sea ice, marine mammals and underwater anomalies. The result was that, in defending British units from the attentions of two active Argentinian submarines, the Royal Navy expended 31 anti-submarine torpedoes, 49 depth charges and 21 anti-submarine mortar rounds. One Argentinian submarine (ARA Santa $F e$ ) was detected and successfully engaged with two depth charges, and no British ship was hit by submarinelaunched weapons. However, as the purpose of anti-submarine warfare is not necessarily the destruction of submarines, but to prevent them from having an influence on operations, the British forces can be considered operationally successful in this regard.

There is also a tendency in strategic assessments to be complacent, if not disingenuous, about the effectiveness and reliability of weapons systems 
and sensors; systems are rarely tested against the rigorous criteria required in war, and there is casual acceptance of underperformance and failure in peacetime. The principal British SAM systems have already been mentioned. It will be recalled that Argentinian mechanical bomb fuses failed to arm (at extremely low levels) and the ST-4 torpedo in the submarine San Luis was operationally incapable of use. The commanding officer of the British submarine Conqueror chose to use stolidly reliable Mk 8 torpedoes instead of the modern Tigerfish versions against the ARA General Belgrano. ${ }^{26}$ This aspect reinforces the need for rigorous testing and regular firing regimes in peacetime to build assurance about the performance of these systems under pressure and when it counts. It is not sufficient to rely on built-in testing and simulation, but to persist with live fire test demonstrations, not only to give operators experience of live firing (the smell of cordite and the moral component), but also to advertise effective capabilities to one's potential (and possibly eventual) opponents.

\section{Procurement}

One of the persistent weaknesses in defence programming is the sacrifice of capability in order to meet price and time criteria, thereby eroding the connection between strategy, concepts and capability. The assumption is that deficiencies can always be addressed before the platform or system is required to prove itself in combat and that short-term risks can be tolerated in the programme. ${ }^{27}$ This risk is further compounded by the fact that equipment is ordered and procured years in advance of its entry into service, by which time its weapons and systems can be partly or wholly obsolete, unless upgrades or technological insertions are incorporated into a nation's programme.

The British Type 42 destroyer was a case in point. Originally conceived as an advanced anti-aircraft and anti-missile (Soviet variety) platform, it was supposed to have been equipped with next generation radars and a range of capable electronic countermeasures and decoys, as well as a maga-

26 This experience recalls the poor performance of British, German and US submarine-launched torpedoes in the opening years of World War II contrasted with the high levels of reliability and operational effectiveness of Japanese torpedoes, notably the 'Long Lance'.

27 'Management risk' has long been defined in the Royal Navy as the risk that managers took safe in the knowledge that they would never be exposed to the risk that they were proposing. 
zine that would hold up to 40 SEADART SAM missiles. It was to have a standard 4.5-inch gun and a LYNX helicopter. ${ }^{28}$ At one stage, it was proposed that the ship should have two lightweight SEAWOLF short-range missile launchers. In the event, the first of the class, SHEFFIELD, and her first three sisters were commissioned into Royal Navy (and Argentinian) service with radars and combat systems that were already obsolete, a poorly performing jammer, a SEADART magazine size of 20 and an ageing WASP helicopter. SEAWOLF had been shelved.

The problem here was that the policy assumptions and concept were compromised by a largely undisclosed, cumulative risk being built into the capability. It relied on this bluff never being called. Unfortunately, the Type 42's bluff was called, with tragic consequences, as the ships that were originally envisaged were not the ones sent to the Falklands. ${ }^{29}$ In the modern fast-paced technological and diverse threat environment, these factors argue strongly for modular and software-enabled applications and frequent technology insertions, linked to common power and digital frameworks.

\section{Information}

An aspect that was peculiar to the Falklands crisis was the way in which information and public participation were tightly contained and constrained. The remoteness and inaccessibility of the islands, as well as the limitations of communications and security considerations at the time, meant that media coverage and public scrutiny were severely restricted. Even the journalists who were embedded with the Task Force, both ashore and afloat, could only send their copy through military communications circuits, with the timing and content largely determined by political and military considerations. ${ }^{30}$ All other print and broadcast information would take at least two weeks to emerge via Ascension Island. Similarly, public participation was discouraged, not only by the dangers inherent in being in a potential or actual combat theatre and the imposition of an exclusion

28 Leo Marriott, Combat Ships 3: Type 42 (Shepperton: Ian Allen Ltd, 1985).

29 It is significant that the subsequent Batch II and, in particular, the Batch III of the class reflected the lessons learned from the Falklands and, in part, the original concept.

30 This aspect did not prevent the BBC in London speculating (accurately) about imminent British action against South Georgia and Goose Green and revealing that Argentinian mechanical bomb fuses were malfunctioning. 
zone, but also by the challenges presented by the weather and environment.

This is not likely to be a situation that will be repeated. Today, one can anticipate the difficulties for the combatants associated with modern communications, sensors and attitudes. It is not difficult to envisage commercial satellite and online media exploitation of a situation, the appearance of extraneous drones and manned platforms, attempts by both state and amateur hackers to interfere in all aspects of the electronic battle and the exposure of critical units through betrayal of their electronic, infra-red or physical signatures. It is possible that the integrity of an exclusion zone at sea imposed by one side or the other could be compromised by large numbers of fishing or other civilian vessels intruding to confuse and complicate situations. The ability of authoritarian states to generate this type of confusion has been demonstrated in disputes in various exclusive economic zones. ${ }^{31}$ At the same time, the proliferation of high-end modular weapons and sensor systems in an increasing diversity of civilian platforms will further complicate ISTAR (Intelligence, Surveillance, Target Acquisition and Reconnaissance) functions. ${ }^{32}$

\section{Conclusion}

The key lesson from the Falklands conflict is that allied or national navies - and armed forces in general—should not rely on the imperfect assumptions that underpin peacetime-generated strategy, complacency about partnerships and abstract policies when they are likely to be faced by high-impact warfare in relation to the political outcomes that they are tasked to deliver. In a world of strategic competition, the likelihood is that only real, demonstrated and immediately available and collective combat capabilities will be sufficient to both prevent conflict and deter opportunists and potential aggressors at every level of interaction. In order to prepare for these eventualities, it is necessary to rigorously interrogate and analyse the totality and variety of the contexts in which political and military objectives

31 Korkmaz, H., 'Hybrid Warfare and Maritime Militia in China'. https://www.aa.co m.tr/en/analysis/analysis-hybrid-warfare-and-maritime-militia-in-china/1897259.

32 Such as the ability to deploy container-based surface-to-surface weapons. https://w ww.navalnews.com/naval-news/2020/08/russian-navy-to-begin-trials-of-modular-sy stems-for-surface-vessels/ and https:/www.navyrecognition.com/index.php/news/ defence-news/2019/april/6971-china-is-building-long-range-cruise-missiles-launche d-from-ship-containers.html. 
might be realised and to assess within that context whether the allied or national military ways and means are sufficient and appropriate in order to achieve success, mitigate the identified risks and cope with the inevitable operation of chance.

As Nelson wrote, 'Something must be left to chance; nothing is sure in a sea fight above all'. ${ }^{33}$

\section{Works cited}

CMND 8288, 'The UK Defence Programme: The Way Forward, London: HMSO, 1981.

CMND 8758, The Falklands Campaign: The Lessons, London: HMSO, 1982.

Frank, Richard B., Guadalcanal, New York: Random House, 1990.

Korkmaz, Huseyin, 'Hybrid Warfare and Maritime Militia in China', Anadolu Agency, 2 July 2020, https://www.aa.com.tr/en/analysis/analysis-hybrid-warfare-a nd-maritime-militia-in-china/1897259, accessed 12 January 2021.

Marriott, Leo, Combat Ships 3: Type 42, Shepperton: Ian Allen Ltd, 1985.

McMaster, Herbert Raymond, Battlegrounds: The Fight to Defend the Free World, New York: William Collins, 2020.

Navy Recognition, 'China is building long-range cruise missiles launched from ship containers', 8 April 2019, https://www.navyrecognition.com/index.php/ne ws/defence-news/2019/april/6971-china-is-building-long-range-cruise-missiles-lau nched-from-ship-containers.html, accessed 12 January 2021

Nicolas, Sir Nicholas Harris (ed.), The Dispatches and Letters of Vice Admiral Lord Viscount Nelson with Notes, London: H Colburn, 1866.

Vavasseur, Xavier, 'Russian Navy to Begin Trials of Modular Systems for Surface Vessels', Naval News, 3 August 2020, https://www.navalnews.com/naval-news/2 020/08/russian-navy-to-begin-trials-of-modular-systems-for-surface-vessels/, accessed 12 January 2021.

33 Sir Nicholas Harris Nicolas (ed.), The Dispatches and Letters of Vice Admiral Lord Viscount Nelson with Notes (London: H Colburn, 1866), VI, 19. 